\title{
Arabs and Euro-Asian maritime contacts
}

\begin{abstract}
The Asian continent has been home to great civilizations like the Indus Valley, Achamenian, Sassanian, Chinese, Mesopotamia, Dilmun and many others. Some also flourished in present day Oman, Syria and many other parts of Asia. Throughout history there has been vigorous interaction among the peoples of Asia leading to trade and cultural links. Indian influence extended too much of present day South-East Asia to what is known as 'Greater India'. Buddhism played a leading role in this field which is still visible through temples and cultural influences. Similarly to the Western part of Asia, Indian influence at one time extended to the entire area inhabited by the Kurds, Central Asia and the Gulf Region. Before accepting Islam, the Kurds were followers of Buddhism.
\end{abstract}

Keywords: civilizations, buddhism, arabs, egyptians, fishing
Volume 3 Issue 3 - 2018

\author{
AK Pasha \\ Professor, Jawaharlal Nehru University, India
}

Correspondence: AK Pasha, Professor, Jawaharlal Nehru University, India, Email drakpasha@gmail.com

Received: November 27, 2017 | Published: May 24, 2018

\section{Introduction}

The Nabateans who established a powerful empire in much of West Asia from Petra now in Jordan are referred to as vegetarians thought to have migrated from India. The Gulf region has seen continuous maritime contacts with Gujarat and the West Coast of India. Navigators from both sides benefited with exchange of goods and ideas thereby enriching their culture and society. Many traders and peoples from both areas especially settled (In both the regions). With the spread of Islam, Arab traders and Sufi Saints from the Gulf region added to this relationship and ties were consolidated. Many Indians converted to Islam, Christianity and Syrian Christians and monks settled in Kerala, the West Coast and other parts of India. Many Jews who could escape persecution from the Romans in West Asia also settled in Kerala and along the West Coast of India. Large numbers of Indians regularly visit religious places in the West Asian/Gulf Region like Mecca, Medina, Jerusalem, Bethlehem, Najaf, Karbala, Mashed so on. The discovery of direct sea route from Europe by the Portuguese sailor Vasco da Gamma to Calicut in Kerala in 1498 and the subsequent European colonialism disrupted the close interaction India had with the Gulf region. After defeating Haider Ali's son Tipu Sultan in 1799 (the last Indian ruler who seriously challenged them) at Mysore, the British consolidated their rule in India. From Bombay with the assistance of Indian soldiers and administrative staff the British controlled bulk of the Gulf region (present day GCC states). Large segments of the Gulf population who thrived on lucrative trade with India and beyond were now virtually dependent on the British dominated trade and maritime links. They Gulf Arabs reverted to pearl fishing and the British transported their principal day to day requirements mostly from India. Many Indian families especially from Sind, Kutch and Gujarat settled in the entire Gulf region. People in the Gulf region now saw Indians as collaborators with British imperialism. The British deported undesirable people from the Gulf region to India. Also some Gulf merchants settled in India, mostly in Bombay. The British who promised independence to the Arabs before and during the First World War, failed to keep up their promise. The Sheriff Hussein of Mecca who was promised a United Arab Kingdom over the liberated Arab lands from the Ottoman rule found British and French rule over Palestine, Iraq, Syria and Lebanon under the mandate's rule of the League of Nations. The Sheriffs two sons were installed as Kings of Iraq and Jordan. The Jews were also promised a homeland in Palestine through the Balfour Declaration. The Mufti of Jerusalem accused the British of having a design to settle in Iraq "many million Hindus from British India". Hundreds and thousands of Indian soldiers died suppressing the Arabs who were opposed to imposition of monarchies, mandated rule and direct British/French occupation. Elsewhere in West Asia thousands of Indian soldiers died fighting with the British during and after the war. The article makes an attempt to capture the deeper significance of the interdependent nature of history and the linkages between military, societal, economic and political foundations of history. It focuses on Egypt as a link between Europe and Asia especially in relation to the spice trade which formed the basis for interaction. Ottoman Turkey has also been an important link as it had become a Eurasian power which is studied as the basis of historical analysis. The military conquest and colonization of India and major parts of Asia by the Europeans was a consequence of superior technology India's advantage at the moment in IT is fast changing its image around the world. India's present economic progress is linked to its past and a combination of new technology, family values, commitment to democracy and multicultural secular society.

Throughout history Egypt has been an important link between India and Europe for trade, political, cultural and other relations. India and Egypt have had close political, economic and cultural relations. Contacts have been through land and sea. The oldest recorded maritime contacts have been between India and Egypt. It is remarkable that both the countries despite having suffered several invasions and attacks have maintained their civilizations. The Nile and Indus valley civilizations and cultures have produced outstanding things in all fields and shared with the rest of the world. Many civilizations like the Dilmun, Magan, Summerian and many others have flourished in West Asia but it is the Egyptian civilization that has managed as the only civilization continuum in the world along with Indian. The Egyptian Pharanoic civilization has been historically linked with Hinduism in India especially in religion and culture. It is remarkable that the ancient Egyptians worshipped the same Gods as Indians. There is unique resemblance in the building of temples and their architecture. Painting and sculpture are very similar. Both appear to have shared a long history of vibrant interaction and such ties between the two peoples have unmistakably continued into the modern period. Indian textiles were familiar in Egypt. During the Roman period Egypt was an important link and India prospered due export of spices and other products. There was outflow of gold from Rome to India which 
became a matter of concern to the Romans. The colonial domination of the Indian Ocean since 1500 affected both the countries that came under British domination. These were the 'lost five centuries' and due to its impact both lagged behind. It was natural that after independence both established close ties in all fields. Whereas Egypt had to face Western-Israeli hostility, India was saddled with partition of the country and attacks from China and Pakistan. Both the countries have faced similar number of wars and have been struggling to regain the stability and prosperity. Nehru recognized the importance of Egypt and established close ties and Nasser reciprocated. Whereas Egypt drifted since 1973 and established close ties with the US due to peace with Israel, India managed to retain autonomy in its foreign policy. Since 1991 India has also been striving to have close ties with the USA along with economic liberalization. Both have been working to strengthen their bilateral ties and the levels of political exchanges have increased giving a new dimension to their ties. Economic cooperation has increased in a number of fields and Indian investments in Egypt are also increasing. But bilateral relations cannot be based only on political and economic relations without strong cultural people to people bond. Given their long historical links the relationship in future can be built on the strong foundation which already exists. This article makes a modest attempt to analyze in a historical context political, economic and cultural relations between India and Egypt who can contribute as major powers in their respective regions to peace, security and stability.

The oldest known civilization identified by historians worldwide is without doubt the Nile based followed by the Indus and Mesopotamian civilizations. Both the Nile and Indus Valley civilizations were in constant contact through land with each other through the Tigris and Euphrates based civilization as also through maritime contacts directly. According to historians from the time immemorial there existed peculiar and deeper relations between India and Egypt. "The Indus civilization was built upon the same primary inventions and discoveries as the Nilotic and the Mesopotamian. Its authors may even have included men of the same racial types". ${ }^{1}$ Dr. MA Murray says: "The type of men of Punt, as depicted by Hatshepsut's artists, suggests an Asiatic rather than an African race; and the sweetsmelling woods point to India as the land of their origin. A voyage from Egypt to India by coasting vessels would be quite feasible and undoubtedly ports for the Indian trade existed along the south coast of Arabia". ${ }^{2}$ India's recorded interaction with Egypt started since the third millennium before Jesus Christ. In ancient Egypt, perfumes utilizing various Indian aromatics played an important role in worship, which in turn led to brisk trade. The Ishmaelites who bought Joseph from his brothers were en route to Egypt with an unspecified range of spices: They saw some Ishmaelite on their way coming from Galaad, with their camels, carrying spices and balm and myrrh to Egypt. ${ }^{3}$ The Egyptians were fond of aromatics and they procured it from a semi mythical place known as "Punt". To get aromatics the Egyptians sent the first recorded merchant fleet to punt which continued to supply to the temples and God-kings of the Nile Pharaohs for thousands of years. The first known maritime trip to Punt took place during Pharaoh Sahure [2491-2477 BC]. Not only had the Egyptians had close trade relations it is well known that Egyptian mummies were reportedly wrapped in Bengal Muslin cloth. Some writers have tried to establish a close link between Egypt and parts of Bengal in India. These similarities led historians to conclude that there was a conquest of Bengal by the heretic kings of Egypt of the XVIII dynasty who were driven out of Egypt by the orthodox school of Amon worshippers sometime between 1358 and 1355 BC. ${ }^{4}$ Around $1500 \mathrm{BC}$ the famous Egyptian Queen Hatshepsut sent a great naval expedition to Punt. This is visible still on the walls of the temple of Dier al-Bahri carved at the orders of Queen Hatshepsut around 1495 BC. A fleet of five ships with mariners on top of ships, rowers, steersmen passing through a huge water body is depicted. These ancient sailors brought back to Egypt from the land of Punt, "all goodly fragrant woods of God'sland, heaps of myrrh resin, with fresh myrrh trees, with ebony and pure ivory, with green gold of Emu, with cinnamon wood, kheyst wood, with ihmut-incense, sonter-incense, eye-cosmetic, with apes, monkeys, dogs and with skins of the southern panther, with natives and their children". 5 The mariners also brought fragrant plants for the temple gardens. She also sent the mission to India perhaps seeking to establish commercial and diplomatic ties between India and Egypt. Not only this initiative from the Egyptian Queen led to the direct maritime communications between India and Egypt several centuries before Christ but more significantly it showed that Egyptian sailors were able to navigate the Red Sea in appropriate time to make use of the Arabian Sea monsoons to reach India and Sri Lanka and maybe perhaps beyond. From modern Somalia the ancient Egyptians continued a voyage of more than two thousand miles south ward. The Egyptian ships also took Indian products like silk, perfumes, spices, medicines, rare fruits, sandal wood, incense and other items not available in the Nile valley. It is mentioned that the Egyptian sailors must have observed the Indian festival of lights - Diwali - because Egypt also has a similar state festival of lights celebrated for nine days. According to Hassan El Zayyat, this unique interaction is a proof "that the ships sailing to India did not serve the purpose of commerce only but also carriers of Indian culture." Ramses III also sent an expedition to Punt. That Indian spices were an important link with Egypt is clear by the discovery of dhania (the umbelliferous fruit of the coriander plant) in the tombs of the Pharaohs especially Ramses. Its identity was confirmed in 1975-76 at Musee de L' Houmme in Paris, after long years of research that the spices came from the south of India. The Pharaoh's were obsessed with eternal life and in order to preserve the body from decomposition they used pepper as a preservative. "It was in all likelihood the supreme metaphysical importance of this end that accounts for the Egyptians extraordinary efforts to obtain a spice all the way from India". ${ }^{7}$ Pepper was not only inserted in the nose of the Pharaoh but researchers also found traces of the spice in his abdominal cavity. Clearly this spice from India was familiar to ancient Egyptians. According to archaeological evidence, there was resemblance between a number of methods used in certain activities such as fishing, boat construction, measuring and weighing in both civilizations.

Between $200 \mathrm{BC}$ and $200 \mathrm{AD}$ an Indian colony existed in Alexandria which was intellectually capable of influencing the Hellenistic scholars and philosophers of Alexandria. Ashoka the Great sent an Indian diplomatic mission to the Ptolemaic court in Alexandria. In the $6^{\text {th }}$ century $\mathrm{BC}$ the Achaemenians who ruled from Iran controlled Egypt and Sind and to improve the communications built a canal linking the Nile with the Red Sea which was beneficial to trade between India and Egypt. Trade between India and Egypt under the Pharonic rulers or otherwise greatly influenced both the societies. As we have seen earlier it carried the culture from one civilization to another. When people move from place to place along the trade routes they carry ideas, philosophy, religions, customs, traditions, rituals as also books, handicrafts and artistic items which familiarize people in different societies. Due to the long sea coast both India and 
Egypt derived considerable revenues from trade in ancient times. As during the modern period, in ancient times also culture and civilization aspects followed trade and commerce between India and Egypt. Along with the maritime contacts referred to between India and Egypt, there existed considerable trade through the land route via Iran, Babylon, Oman, Aden and Palestine and onto Egypt. For the ancient period, one has to rely upon direct archeological evidence like seals made of ivory, stone, terracotta used in those lands or the use of Indian or Egyptian names for such items. In the second century BC an Indian sailor offered to show the Romans (who were ruling Egypt) the shortest direct sea route to India. Ptolemy Euergetes II (145-116 BC) the Roman ruler of Egypt welcomed the proposal and directed Eudoxus, a Greek [Cyzicus] explorer, to set out with the Indian across the high seas to India. The Greek made two trips to India to buy spices and other eastern luxuries which Ptolemy seized. ${ }^{8}$ This was a turning point in ancient Indo-Egyptian maritime links as it heralded direct trade contacts under the Greco-Egyptian dynasty of the Ptolemy's which declined with the demise of Cleopatra. The previous maritime contacts were not regular because the sea journey was long and arduous as the small ships had to sail along the coasts and hence target of pirates. When the Roman Emperor Augustus annexed Egypt in 30 $\mathrm{BC}$ he built new ports on the Red Sea and dug wells along the caravan routes crossing the desert from the Nile to the Red Sea. The Romans soon subjugated the Nabateans and the Hadhramauti merchants who had dominated the spice trade especially in the Red sea area. King Kaniskha was familiar with Rome. The description of India by one Roman Apuleiu's [124 AD] is interesting: "The Indians are a people of great population and vast territories situated far to our east, by the Ocean's ebb, where the stars first rise at the ends of the earth, beyond the learned Egyptians and the superstitious Jews, Nabataean merchants and flowing-robed Parthians, past the Iruraeans [Palestine] with their meager crops and the Arabs rich in perfumes-wherefore I do not so much wonder at the Indians mountains of ivory, harvests of pepper, stockpiles of cinnamon, tempered iron, mines of silver and smelted streams of gold: nor the Ganges, the greatest of all rivers and the King of the waters of the Dawn, running in a hundred streams... ${ }^{\prime}, 9$

During the second half of first century 24 AD a Greek sailor, living in Egypt sailed to India through the Red Sea and along the coasts of Arabian Sea and recorded his experiences in a book called "The Periplus of the Erythraean Sea”. The book a pilot's guide to sailing in the Indian Ocean telling each step of the long and perilous sea journey also highlighting the ports and harbors to halt and what goods to acquire and sell over there. The water body between Red Sea, Persian Gulf and the Indian Ocean and beyond is called as the Erythraean Sea. The Romans who controlled Egypt sent ocean going ships to India. One Greek sailor named Hippalus found out the annual cycle of monsoon which was the secret of navigation in the Indian Ocean. The Romans apparently called at any one of the 19 Indian ports in which, in the words of the Periplus, "great ships sail...due to the vast quantities of pepper and malabathron". It clearly reveals the extensive trade ties between India and Egypt as Roman and Indian ships sailed to coasts all along Oman, Yemen and to the Red Sea [Horn of Africa known in ancient period as Cape Guardafui or Cape of Spices] carrying among other things sugar, pearls, precious stones, spices, unguents and cotton clothes - Muslin all of which were in great demand. In many of these ports/harbors on the sea coast Indians had settled for trade and that

${ }^{1}$ Sir George Watt. The Commercial Products of India. London: 1908. Turner, n.3.pp.63-64.
Aden and the Socootra Island had a colony of Indian merchants. ${ }^{2}$ Many Indian Kings especially from South India, the Pandyas sent trade missions to Rome to the Emperor Augustus around $26 \mathrm{BC}$ as also during subsequent period. Indian goods were carried by sea upto the Red Sea Coast and from there to Alexandria. The Gangas of Talakad in South India had flourishing trade with the Roman Empire as this is corroborated by the recent discovery of a large number of Roman coins in the temple town of Muduktherai on the banks of Kaveri which must have been sent for Indian goods shipped to Alexandria as similar coins were discovered over there. Thus, both India and Egypt not only had direct trade ties but Egypt especially Alexandria became the entreport for Indian goods to Europe.

The Romans through the Egyptians exported to India glassware, works of art, tin and Mediterranean coral-much prized in India for its imputed magical properties and bullion. They brought back from India ivory, pearls, tortoiseshells, diamonds, onyx, agate, crystal, amethyst, opal, beryl, sapphire, ruby, garnet, bloodstone, emerald, carnelian, linen, textiles, wheat grains, handicrafts and many handmade art products. Silk from China was also brought via India. Animals from India like parrots, tigers, rhinoceroses, elephants were also brought. But it was clearly the Indian spices which were the main attraction along with costus, nard and cloves as well. The ancient Egyptians visited India frequently not only for the goods they needed but also to sell Egyptian products in the vast Indian market. It is recorded that Ptolemy II [ruled 285-246 BC] exchanged ambassadors with the Mauryan Emperors Chandragupta II [321-297 BC] and Ashoka [232 BC]. Alexandria in Egypt, ruled by Ptolemaic and Roman rulers being cosmopolitan city, was not only a major trading center but far ahead of Rome and Athens culturally. Alexandria became the chief port of the Nile delta. The route from Alexandria to Rome was the most heavily trafficked trade route of the ancient world. Within weeks of sail brought prized goods including much sought after spices to Rome's great port at Ostia at the mouth of the Tiber. The distance was about 5000 miles from India. Thus, Alexandria was not only a place where traders from all parts of the world met, but the cosmopolitan city also attracted scholars from all over the world especially from India who interacted with their Egyptian counterparts. Apart from the trade ties between India and Egypt, the Egyptian mind was also influenced by Indian mysticism, especially the doctrine of rebirth. The ties in historical period were further intensified during the Roman period. As more and more Persians began to take interest in commercial activities, direct Indo-Egyptian trade relations in the second and third century AD declined. Although the discovery of monsoon winds in $\mathrm{AD} 44$ had changed the maritime contacts between the two countries and the volume of trade had increased in first $\mathrm{AD}$ with every year around 120 ships traveled to India for various products, but the contacts decreased subsequently due to decline in Roman power in the aftermath of the invasions by barbarians [Franks, Visigiths and Alamannis] shattered the prosperity and order on which trade with India depended. The Gothic invaders who dismembered the Western Roman Empire dealt a severe blow to trade with India. This decline persisted for about 1000 years but sporadic demand for Indian goods remained despite invasions and disruptions. During the period of Pliny the Elder [23-79 AD] Rome's cosmopolitan tastes had reached such a pitch that he talk of the flavors of Egypt and India appearing in Roman kitchens. ${ }^{3}$

Egypt and India greatly benefited from trade with the Roman

${ }^{2}$ Zayyat, n.4, p.14;

${ }^{3}$ Ray, n.1, p.38. ; Turner, n.3, pp.238-39. 
Empire and as one writer said: "the money flowed out to foreigners". Gold and silver Roman coins reached India in great quantities as visible in the vast archaeological discoveries in South India particularly. Pliny the Elder apparently "complained that India swallowed up the colossal sum of 50 million sesterces per annum- all for the sake of pepper and other "effeminate" eastern fripperies. India and its luxuries were turning Rome into a city of wimps". India and its pepper became almost paradigmatic. To Pliny the Elder, the voyage to India was no more than a grubby quest for loot, "and so India is brought near by a lust for gain". ${ }^{4}$ After the reign of Caracalla [211-217] roman coins declined in India. Soon the Roman Empire suffered one disaster after another affecting the eastern traffic. More over the Red Sea littoral passed under the control of the Blemmyes, a hostile African tribe and Rome's direct trade route via Egypt was disrupted. But the Byzantine state maintained even in the sixth century a customs official at Clysma on the Gulf of Suez and a famous Greek-Egyptian monk Cosmas Indicopleustes traveled to India around $550 \mathrm{AD}$. The transformation was already visible as Syrian, Latin and Hebrew were the languages used by the merchants all along the spice routes. Socootra Island situated at the Bab el Mandeb near Yemen was an important link in Indo-Egyptian contacts. The memory of this trade still survives in western India especially among the people of coastal Gujarat who worship a goddess called Sakotri Mata, named after Socootra Island. ${ }^{10}$

The spread of Islam under Amr-ibn-al-As in major parts of Egypt brought Arabs from the heart of Arabian Peninsula to a country where idolatry, temples existed. Pharonic culture was widespread despite the growth of Christianity, but modest trade especially Egyptian imports of Indian textiles continued. Fragments of fabric were found at Al Fustat near Cairo which functioned as a major trading center in Egypt. Initially the direct maritime trade contacts appear to have declined since the rise of Islam between India and Egypt as the Arabs from Oman, Yemen and others like Persians began to interact with Indians on a bigger scale converting the Indian Ocean as a Muslim lake. Muslim merchants especially Arabs were now firmly established from Malacca, Malabar to Maghreb to China. The Arabs traders and mariners [Muslims] now controlled land and sea routes and used camels and ships to transport goods. The Jews now were also active with the Muslims. But Indian goods especially spices continued to reach Cairo in modest quantities for onward transmission to Europe in return for furs and amber from the Baltic's; slaves, timber and metals from the Alps and the Balkans. To one writer "pepper has perhaps been the oldest continuous link between India and Egypt and also between Asia and Europe and one that has survived, battered but intact, ever since". ${ }^{5}$ Under these circumstances Alexandria became once again the terminus of transcontinental trade as it had become famous earlier during the Romans. Trade ties between India and Egypt were revived through the Red Sea and once again there was brisk trade. During this period the "Syrian" i.e. Byzantine merchants [Constantinople still remained the capital of the Eastern Roman empire until 1453 when the Turks took over] and the Jewish traders also began to play an important in the trade between India and Egypt. The Jews were uniquely placed as a link between the Christians and Muslims. Many writers refer to a loose alliance of Jewish merchants known as the Rhadanites whose name appears in the Book of Routes composed around 850 by Ibn Khordabeh, Director of Posts to the Caliphs at Baghdad. The Jews were present all along the old silk route

${ }^{4}$ Ibid, p.11 and 13; S. Maqbul Ahmad, India and the Neighboring Territories (Leiden: 1960). ;Turner, n.3,pp.82

${ }^{5}$ Ibid. p.48; M A. Saleem Khan, Early Muslim Perception of India and Hinduism (New Delhi: South Asian Publishers, 1997).Turner, n.3, pp.66 from Gaul to China. Interestingly the arrival of Muslims [Islam] at the gates of Arles and Marseilles [France] and at Saint Peter's Basilica in 846 propelled the Jews to prominence as even Charlemagne and his Frankish nobles were forced to rely on Jewish merchants for their luxuries. Due to their new role, Christian persecution of Jews virtually stopped as also forced conversions common during the Frankish Dynasty Merovingians dynasty [476-750] in Europe. It must be noted that one of the oldest surviving decrees of the Venetian Senate forbade Jews from traveling in Venetian ships. ${ }^{6}$ The Jewish presence was noticeable due to the Fatimid Dynasty's [969-1171] connections with Maghreb areas. Like the Romans the Fatimids encouraged trade through the Red Sea by maintaining a strong navy and providing security to merchants from all over the world. According to one writer, Cairo was then embarking on the period of its greatest commercial splendor, drawing commerce, merchants and travelers like filings to a magnet. Alexandria regained the position it had occupied in classical antiquity as Europe's chief point of access to the exotic goods of the East"? In 996, a traveler to Cairo counted 160 merchants from Amalfi alone. Nahray ibn Nissim, a Tunisian Jew settled in Egypt, was dealing in products as diverse as Spanish tin and coral, Moroccan antimony, Indian spices, Armenian clothes, rhubarb from Tibet and spikenard from Nepal. The Jewish trade connections came to light from the remarkable collection of business papers, belonging to Jewish merchants, discovered in a Synagogue of Old Cairo. The documents, letters, etc. cover the period 1000 to 1250 . The commercial contacts of the Genizah (Cairo) Jewish merchants under the trading guild known as the Karimis existed through their agents from China through India to Morocco and were an important link between India and Egypt. The intermediaries in most cases were Jews themselves. According to KN Chaudhri, "Business was done by consigning goods to friends and relatives in Fustat or Aden, which the principal remained in India. It is significant from the point of view of commercial organization that the leading Jewish merchants of the period with business connections in distant countries did not find it necessary to travel with their own goods". ${ }^{11}$ The major items imported from India were spices but also included sandalwood, camphor, cloves, nutmegs, cubebs, coconuts, flaxen and cotton fabrics and ivory, pepper, lead, Kutla drug, bamboo, cane precious stones, cardamom, cinnamon, aloes, marjoram, myrrh, galangal, mastic, vermilion, parrots, saffron, mustard, cassia, garlic, musk, ginger, pearls, crystals and Sanbazaj (used for polishing stones). Wine and scents were imported from Egypt. Many Arab Egyptian merchants settled on India's western coast like Gujarat, Konkan and on the Coromandel Coast. Jeddah now became an important link for trade between India and Egypt due to the trade being in Arab hands and also due to its proximity to Mecca -the pilgrimage center for Muslims from all over the world. Large number of Indian scholars visited parts of the Arab world especially to Baghdad the capital of the Abbasid Empire taking with them their works in Sanskrit on astronomy, mathematics and medicine which were translated into Arabic and Greek. Gradually Islam began to influence India first through Arab traders in the coastal areas and later from Sind, Persia and Central Asia.

During the Fatimid period in $10^{\text {th }}$ century AD the Egyptian merchants were famous as El Karemia who traded mostly in Indian

${ }^{6}$ Ibid, p.49; NA Faruqi, Early Muslim Historiography: A Study of Early Transmitters of Arab History from the Rise of Islam to the end of Umayyad Period, 612-750 (Delhi: 1979).Turner, n. pp.96-7.

${ }^{7}$ M.K. Dhavalikar, Early Contacts, in Doshi, n. 4, p.50. See also S. Maqbul Ahmad, Indo-Arab Relations (Bombay: Popular Prakashan, 1969).Turner, n., pp.104. 
spices. Very often these merchants stayed in India for long periods and often married with Indian women. They also played in important role in spreading Islam in India. These Egyptian spice merchants came to be known as Bohras (apparently from bahar-spices or bahar (outside). The Bohras still are a very important Indian trading community in Egypt -Cairo in the business as well as a link between the two countries. According to Sahar Abdel Aziz Salem, the Fatimid zeal to spread Islam in India indicates their desire to preside over the trade of the Indian Ocean. This could strengthen the economy of the Fatimid Caliphate in Egypt while at the same time weaken that of the Abbasids (at Baghdad). ${ }^{8} \mathrm{He}$ also argues that many Indian traders also visited Egypt as "Indian penetration into the Red Sea might have also taken place in the Fatimid period when relations between Egypt and India were very close and friendly, since they combined both commercial and spiritual interests". It appears Mohammed bin Tughluk Shah (who was known as the Sultan of India but also of Sind, Makran, Mogadishu and Sri Lanka) sent a ship to the Egyptian Mamluk Sultan Al Naser ibn Qalaun full of precious presents and diamonds, but it could not reach Cairo as the King of Yemen looted it. This clearly reveals that Indian ships were famous in Red Sea, Aden and along the Arabian coast. Egypt under the Fatimids flourished due to the brisk trade with India. Indian influence is seen in Egyptian mosques, especially design of the minaret as large number of Indian ships carried Moslems for Hajj and other Holy places. Egypt under the Fatimids continued to the extent possible interaction with India in trade and other fields. Since the entire Gulf region, Arabian Peninsula and North Africa including Egypt was undergoing rapid transformation under Islamic rulers this naturally affected the cultural relations as the Indian society was also undergoing similar changes in pockets of India under Muslim rulers both in north and South India. The Spanish Rabbi Benjamin of Tudela visited Alexandria in 1160 and found European merchants like Italians, Catalans, Frenchmen, English and Germans rubbing shoulders with merchants from all over the world. This is interesting in the background of fierce religious wars in Europe. The Fatimids encouraged trade as they needed customs duties. Egypt also continued to be the link to the extent possible between India and Europe and interaction with India was very lucrative especially in spice trade and other fields. During 1170-1260 the Fatimids in Egypt were replaced by the Ayyubid rulers under whom the total volume of trade declined as the European traders began to take active interest and increase their share. Moreover the sea route to India became vulnerable to pirates and growing incidence of taxation. Some wealthy Egyptian merchants began to buy protection from rulers in the coastal regions to protect their ships from the menace of pirates. The role of Jewish merchants/ agents (who could speak many languages) increased all along the routes from Alexandria, Jeddah, Aden, Muscat, Basra and Bushier and to the Indian Coast. This may also have partly increased the European volume of trade with the East and hence partly contributed to decline in Indo-Egyptian trade. Egypt soon came to be ruled by the Mamluks (1260-1517) and the devastation of the region from Persia to Palestine and the downfall of the Abbasids in Baghdad (1258) due to the Mongol invasion enhanced the importance of Cairo in the trade through the Red Sea area. The crusade attacks and the prominent role of Saladin in defeating the Crusaders led him to contain the growing role of Frankish merchants from gaining direct access to the Red Sea and limited their interaction to the North African and Mediterranean ports. Despite restrictions placed by the Pope on Christian traders for their purchases from Muslim countries, merchants from Genoa ${ }^{8}$ Doshi, n. 4, p.xiv; see also Sahar Abdel Aziz Salem, « Commerce and one Faith », in Doshi, n.4, p.96. and Venetian did trade through Alexandria. The Egyptians conducted trade through "safe conduct passes". The Mamluk rulers assured security to merchants, property and goods etc. It appears during the fourteenth century Egypt and the surrounding areas went through a difficult period due to economic disruptions and consequent decline in trade mainly due to the Black Death in Egypt in 1347. Religion again came as a hindrance in Indo-Egyptian trade as in 1322, the Pope excommunicated many leading citizens of Venice for their dealings with Muslim rulers and for some time a papal ban prevailed which slowed trade with Egypt with its repercussion on trade with India. The trade simply passed into the hands of Armenians merchants from Turkey to Persia to India and the Armenian port of Lajazzo became the link for Europe reducing Egypt's importance. Despite restrictions placed by the Pope on Christian traders for their purchases from Muslim countries, some merchants from Geneo and Venetian did trade through Alexandria. The Black Death in Egypt in 13478, [bubonic plague- Rattus rattus] which divested agriculture and adversely affected the Egyptian population scared the foreign traders. This disease always started at the coast and from there went up into the interior wrote Procopius. Every freighter and galley shuttling from India to Egypt and from Alexandria to Byzantium was, potentially, a "death ship". ${ }^{9}$ According to one writer, "the exact relationship between these events and the rhythm of long distance trade through the Red Sea is not quite clear but the Cairo-Alexandria trade network however, remained open", although it did not see the brisk trade it was used to in earlier periods. It is interesting to know how an Egyptian scholar (historian) of the fifteenth century AD called Al-Qalqashandi appreciates India with these words. "India is a big and wide country having enormous wealth. The king lives with pomp and glory. Its ocean is full of pearls, its earth with gold and its mountains with rubies and emeralds. Its valleys have fragrance of sandal wood and camphor. The people are bestowed with wisdom. Peace and justice can be seen in the entire country". Another modern Egyptian scholar, Abu Zohra, in his book Mohaderat Fi Muqarinat al Adyan opines about ancient Indian religions and says: "Indians have a glorious history. They were possessed of civilization and culture in older days. The history of their civilization is so old that one remains unable to trace its origin". ${ }^{12}$ Soon the crucial areas through which trade between India and Egypt was to pass came under the Ottoman Empire and this led to disruption in commercial transactions due to political troubles especially in Egypt.

But the most significant development came in the Indian Ocean with the discovery of a direct sea route from Europe to India by the Portuguese when Vasco da Gamma with the help of an Arab pilot landed at Calicut, on 21 May 1498 in Kerala. The arrival of Europeans in South India drastically changed the entire scene concerning trade, politics and control of colonies. The Portuguese met two stunned resident Tunisian merchants who spoke Genose and Castilian. Da Gamma also met Italian merchants who had reached Calicut by land route. On March 8, 1500 Portuguese Admiral Pedro Alvares Cabral came to Calicut with 13 huge ships and a thousand strong crew. Soon Cabral demanded the expulsion of all Muslim merchants, [Arabs, Persians, Indian Muslim merchants from Gujarat so on]. When the ruler Zamorin refused, Cabral seized a large and heavily laden Arab ship preparing to sail to Egypt through the Red Sea. He ordered two day heavy bombardment of Calicut destroying most ships and the port. "The Portuguese seized or sank all Muslim shipping they lay their hands on; Muslim merchants were hung from the rigging and

${ }^{9}$ Salem Khan, n.8, p.102; Tara Chand, Influences of Islam on Indian Culture (Allahabad: The Indian Press, 1965); Turner, n.3, pp.180-1. 
burned alive in view of their families ashore...Calicut's fate was just a taste of things to come. In the years that followed, similar treatment was revisited on the city and other Malabar ports.... All to the strategic end of establishing a royal monopoly over trade in the Indian Ocean". The new rulers of the Indian Ocean henceforth ordered traders of all nations to require a permit to sail waters they had freely sailed for time immemorial. "The goal was nothing less than to make the Indian Ocean a Portuguese lake. All competition would be taxed or blown out of water".$^{10}$ Soon they began to take over the spice trade in the entire Indian Ocean region. The Portuguese King Mauuel crowned himself as "Lord of Guinea and of the Conquest, the Navigation and Commerce of Ethiopia, Arabia, Persia and India". The new masters of seas now ordered Venetian merchants to buy spices at Lisbon. Soon there was drastic reduction in the supply of spices to Cairo and Alexandria the traditional markets to which Indian traders supplied via Aden and Red Sea. Since the Turks were also at war with major parts of Europe, this led to rise in the price of spices due to shortage of supply. All this greatly undermined the traditional Indo-Egyptian trade contacts and hence impacted on the cultural and other ties as well. The Portuguese discovered that the price of a quintal [128lb] of pepper in Lisbon was a fraction of that paid in Alexandria for a like amount brought from the Indian Ocean by the traditional route, in Red Sea dhows and on the backs of camels. Even though the treasury of King Manuel was short of money, he enlisted the financial help from Lisbon's wealthy merchants who saw immense profits from direct spice trade with India. Vasco da Gamma again sailed to India in the middle of 1502 now with 25 ships, the ten largest containing 'much beautiful artillery, with plenty of munitions and weapons, all in great abundance.' Thirteen of the ships belonged to wealthy Portuguese merchants. Earlier he had come with three small vessels only. Six of the ships were sent to the Red Sea to put an end to Arab trade ships playing up to the Egyptian ports with spices. On his way to Calicut Vasco intercepted an Arab ship with cargo and hajj pilgrims returning from Mecca. The rich cargo was seized and all 700 passengers were killed in sea 'until the sea is red'. The owner of the ship was the richest Arab in Calicut, a man related to the Sultan of Egypt. De Gamma proceeded to "conquer ...the Indian seas and shores of Asia, killing, destroying and burning the Moors of Cairo, of Arabia and of Mecca and other inhabitants of the same India, together with their fleet, by which for over 800 years they have controlled their trade in precious stones, pearls and spices". On reaching the Indian coast he devastated Calicut upon refusal by the Zamorin to surrender. King Manuel called the destruction of Calicut as 'inestimable damage' and he was told earlier by his spies that the India spice city Calicut was 'bigger than Lisbon'. Not only many people including trader were killed but their ships were also burnt especially of the Arabs. In Calicut one rich Arab merchant Coja Mehmed Markar who traded throughout the Red Sea and much of East Africa and who lived in Cairo was taken prisoner by da Gamma's captain and almost beaten to death and killed. Coja became an enemy of the Portuguese like many other Muslim merchants who not only stayed in Egypt and traded with Calicut and other parts of India but mobilized others to persuade the Ottoman Turks to fight the Portuguese and put an end to their domination of the traditional trade routes in the Red Sea, Gulf and the Indian Ocean areas. Tired of deliberate policy of the Portuguese to obstruct Egypt's trade with India and the spice trade through the Red sea especially which had seriously undermined his finances, the Sultan of Egypt Qansuhah al-Gawri threatened to expel all Christians and destroy the holy places in Jerusalem if Portuguese ships went on interrupting ${ }^{10}$ Chaudhuri, n.11, p.59-60; Turner, n.3, pp.20. trade between India and Egypt. The Egyptian emissary to Lisbon was a Christian priest from St Catherine's monastery on Mount Sinai. The Portuguese King showed his imperious spirit and issued his own threat: "let the Sultan be warned that Portugal intended to do its Christian duty by entering the Red Sea, laying waste to Mecca, destroying the tomb of the 'false prophet Muhammad' and carrying away his remains". Soon King Manuel appointed Dom Francisco de Al Meida as the Viceroy with orders to plunder seize and destroy any ship-especially any Muslim ship- caught on high seas without a Portuguese passport [cartazes]. He ordered the mouth of the Red sea to be closed with a fort to stop any spices being sent to Europe by that route and to "persuade all the people of India to put aside the fantasy that they can ever again trade with any but us".

The Mauluk Sultan of Egypt and the Ottoman Sultan in Istanbul decided to respond to the formidable challenge posed by the Portuguese in the Red Sea and the Indian Ocean. The Turks with the help of the Venetian decided to build a fleet in the Gulf of Suez, Sinai port of Tor. There was a mutual interest in driving the Portuguese out of the spice trade of Indian Ocean and destroying the Portuguese 'floating fortresses. It is interesting to note that the Venetian "had at one stage thought of urging the Egyptians to dig a canal through the Suez peninsula as the easiest way to put ships into the Indian Ocean. They withdrew the idea, fearing that the Sultan would suspect them of wanting to open a route for their own trade." By early 1507 the Egyptians, Turks and the Venetian had completed the building of twelve huge warships. Amir Hussein was made the admiral in charge and he left Tor, Sinai, with his heavily laden warships with 1500 fighting men and their weapons, as well as the best cannons transported in cargo boats across the Mediterranean to Egypt from Turkey "because the Mamluk military caste which ruled Egypt made guns designed only for defensive use on land". It took 8 months for Amir Hussein to reach Diu where Malik Ayyaz, a Russian Christian converted to Islam by the Turks, was waiting to welcome Hussein's fleet. At the same time the Zamorin of Calicut who had also suffered immensely at the hands of the Portuguese sent 100 light vessels armed with cannons made by two Portuguese renegades. These ships were carrying food for the Egyptian naval armada at Diu. They would also give support when battle was joined.

The unprecedented Portuguese and later European challenge at the sea to two very ancient states, cultures and civilizations led to the formation of a unique strategic alliance between India and Egypt not only to checkmate the growing threat to their trade and commerce but to safeguard their interests. In this first known Asian Solidarity Alliance in the modern period--Egyptians, Turks, Kurds and Indians came together containing the formidable Portuguese challenge at sea. The Muslim ruler of Gujarat, Mahmud [I] Begarha, [1458-1511] came to establish a vast empire from Sind to Deccan. Malik Ayaz [died in1522] a Turk, who had found employment in the court of Gujarat, was made Governor of Diu who made the Gujarati coastal city a prosperous place replacing Cambay as the great transshipment center and mart of Gujarat. Diu under Malik Ayaz's rule had impressive fortifications. Ayaz consistently rejected Portuguese demands for a factory and trade concessions. He also controlled Sawarath, Patan, Gogha, Surat and Rander among other areas. The Governor commanded large influence at Mahmud's court and maintained a huge military and a strong naval fleet. His ships sailed far and wide mainly trading with Gulf, Red Sea and East Africa. His navy is said to have comprised at least 100 fustas, each one with 25 pairs of oars, 
one heavy cannon and two lighter pieces. He also had larger war vessels and many armed merchant ships. Mahmud Bergha in alliance with Qwansauh-al-Ghauri, Mamluk Sultan of Egypt, tried to check the rising power of the Portuguese in the Indian seas. The customs revenue of Egypt had been seriously affected by Portuguese attacks on ships carrying spices from India to the Red Sea. As seen before, the Egyptian Sultan sent a naval fleet, under the command of Amir Hussein, the Kurd, Governor of Jeddah, to drive the Portuguese out of the area. The Egyptians had heavier and powerful ships with artillery. The Indian contingent, under the command of Malik Ayaz, had 34 fustas. The historic naval battle between the Portuguese, Egyptians and the Indians took place near Chaul. The combined fleet defeated the Portuguese squadron commanded by Dom Lourenco d' Almeida, son of the Portuguese Viceroy, Francesco de Alameda, near Chaul, South of Bombay, in 1508. The flagship in which Dom Lourenco commanded sank with the rest retreating south. The Portuguese lost at least 140 men dead and many scores were taken prisoners. Malik Ayaz was supported by the Egyptians and ships from Calicut. This victory was short-lived. Soon Dom Lourenco's father Francisco de Almeida, the Portuguese Viceroy on learning about the defeat and death of this son began to plan his revenge attack on Diu and especially the Egyptian naval fleet. He also began contacting Malik Ayyaz to change sides who remained noncommittal. The Portuguese Viceroy D. Francisco d'Almeida on 2 February 1509 reached Diu with a large naval fleet from Goa and found the Egyptian naval fleet lined up at anchor, ordered firing mercilessly at the Egyptian ships and the "answering fire never matched this onslaught". The Portuguese ships some carrying as many as 40 guns, stood higher out of the water, so that their cannonballs hurtled and inflicted defeat on the Egyptian-Turkish fleet. The Governor of Diu Malik Ayyaz according to one source "was a passive onlooker, never firing a shot against the Portuguese attack and keeping his ships well out of range". When Admiral Amir Hussein returned to Istanbul he told the Ottoman Sultan how the naval battle at Diu had been lost and he is reported to have said: "he was betrayed at the crucial hour by the Governor of Diu, who had been born a Christian". The Portuguese intoxicated by their naval victory went about destroying any Muslim ships, ports, harbors, burning cities and killing captains, traders and looting and plundering anything of value in their way of death and destruction. The Portuguese had a new naval commander as Almeida successor, Afonso de Albuquerque, who became the real founder of Estado da India. He was 'fervent in his desire to kill Muslims' and had spent a lifetime of fighting in North Africa before making his first visit at 50, to the Indian Ocean. He "dreamed of using Ethiopia as a base for destroying Mecca and talked of bringing engineers from Madeira to work on the absurd scheme for diverting the Nile into the Red Sea and so starving Egypt into submission". Failing this his first move was to mount an attack on the powerful fortress of Aden, at the entrance of Red Sea because, "it had always been Portugal's ambition to take Aden, for then there could be a virtual blockade against any Muslim ship trying to carry spices on to Egypt". The attack was a complete failure and the Portuguese suffered heavy losses and the only satisfaction they had was in setting fire to all Arab merchant ships in the Aden harbor and in collecting reports that the Egyptians and Turks had not yet started building another naval fleet at Suez.

According to other sources Malik Ayyaz continued to resist the Portuguese demands for a fort at Diu during his lifetime. Mahmud Begarha died on November 23, 1511 The Portuguese position strategically was weak because with no base nearer than Goa or
Hormouz in the Gulf, they were unable to lie off Diu for long in the face of ships fron Malik Ayaz's fleet. Unable to take Diu, the Portuguese continued to raid, sack and burn Surat, Rander, Gogha, Mangrol, Somnath, Bassein and many other Gujarati ports thereby crippling trade with the Gulf and the Red Sea. Subsequently the Portuguese were granted a site for a factory at Diu by Bahadur Shah. This was mainly to stop Portuguese seizures of Gujarati ships trading with the Gulf and Red Sea including ships carrying Hajjes on pilgrimage to Mecca. The Gujarati ruler in order to ward off the growing threat from the Mughal ruler Humayun gave the Portuguese permission to build a fort at Diu in return for their help against the Mughals. The Portuguese even after this concession continued to prohibit Indian trade with the Red Sea. In December 1534 and October 1535, Mahmud Bergha's successor Bahadur Shah signed a peace treaty with the Portuguese Governor Nuno da Cunha whereby the Portuguese were given the port of Bassein and its nearby lands and permission to build a fort in Diu. All Indian ships bound for Red Sea from Gujarat were to pass through Bassein and also return through this port under Portuguese control. The Portuguese who had seen the naval power of the Gujarati rulers now imposed a complete ban on building of warships, nor could they use they already had. Ultimately the Portuguese killed Bahadur Shah treacherously mainly because he was very much interested in sea trade and building a powerful navy. According to one writer: "He traveled frequently by sea and pursued an active policy go building ships for both commercial and military purposes. These ships were admired by the Portuguese themselves and were apparently as large in number of oars as contemporary Turkish vessels Bahadur Shah had a fleet of 160 sail at his death in 1537". He had also been in continuous touch with the Ottoman Sultan "with the object of driving the Portuguese out, not only from Diu but also from India and the Red Sea". The Ottoman Sultan more than once sent ships and artillery of the Ottoman naval fleet to help the Gujarati ruler Bahadur Shah and this was quite effective. After they took over Constantinople in 1453, the Ottomans lost naval supremacy in the Mediterranean in 1571, when they were defeated at Lepanto. The Europeans began to dominate trade in the Indian Ocean and Arab Mudarabah or speculative trade declined, as the former came to dominate the territories as well.

The Ottoman Sultans found they were unable to control the growing Portuguese takeover of vital trading areas in India, Gulf, Red Sea and even in the Mediterranean areas (Ports). At this stage it is necessary to briefly assess the Ottoman Empire's position which was under mounting challenge from the European powers. After they took over Constantinople in 1453 and renamed it as Istanbul, the Ottoman's were undisputed naval power in the Mediterranean. They had achieved unprecedented growth mainly due to their skill in facilitating the transport of the products from the East after taking over the traditional silk routes in Central and West Asia, such as cotton, spices, silk and agricultural produce to Europe in exchange for weapons, ships and manufactured goods. The unprecedented and truly revolutionary geographical discoveries by the Portuguese, Spaniards, Dutch, French, British and others and the direct sea route especially to India led to importation of gold and silver from the new colonies and the almost takeover of Orient trade adversely affecting the Ottomans. Soon the Ottomans were to suffer a terrible defeat in 1571 at the hands of Italians when they were defeated in a naval battle at Lepanto in East Mediterranean. This was seen as a "watershed in the history of East-West Relations." According to one writer, "Once the Ottomans were stopped at Leponto, the continued long-term autonomy of the Western Mediterranean would never again be in doubt. Leponto 
ensured that the growing Atlantic trade with the Americas would continue as Europeans not only became enticed by the New World treasure but found the Ottoman Empire increasingly irrelevant to their growing commercial interests in the Orient via routes around the Horn of Africa." Not only European control and hegemony over the Eastern Mediterranean was restored but the with the rise of the Europeans, the Arab-Islamic lakes as the Indian Ocean, Gulf and Red Sea were known, came to be dominated first by the Portuguese, then by the Dutch, French and soon the British became undisputed masters over the area. The secret was due the fact that the Europeans possessed large number of sophisticated ships with powerful guns than the Ottomans. This also led to the shift in focus from the Mediterranean Sea to the Indian Ocean and the Atlantic. Clearly this marked a new era in which powerful guns, cannons with ships using sophisticated technology proved to be decisive and a real strategic shift. The Ottoman advantage with cavalry was now in changed circumstances not much of an asset compared to ships owned by small states like Portugal or Venice. The Ottomans saw rapid drying of capital with the highly lucrative maritime trade carried by the Europeans with India and the East in general. In 1580 Emir Mehmet ibn Emir es Su'udi wrote: "The Europeans have discovered the secret of Oceanic travel. They are Lords of the new world and of the gates to India.... The people of Islam are without the latest information in the science of geography and do not understand the menace of the capture of the sea trade by the Europeans". ${ }^{11}$

These momentous developments pioneered at sea by the Europeans sent the crucial spice trade shipping from Egyptian/Arab and Persian merchants as the price of spices went up due to war, scarcity of supplies and dislocation of the regular shipping between Malabar, Gulf and the Red Sea. Along with the Egyptian merchants, the Red Sea route was also busy with Persian traders from the Gulf and also the seafaring Omani Arabs. "After a few disrupted decades as the shock of the early Portuguese conquests reverberated back down the spice routes, Alexandria and Venice staged a comeback. In the 1560's, there were so many spices for sale at Alexandria that a Portuguese spy suggested that a Portuguese should abandon the Cape route altogether and ship their spices via the Levant in order to cut costs. So great was the flow of illicit spices through the Portuguese blockade that there was speculation of Portuguese viceroy was in tacit revolt against the King. ${ }^{12}$ The religious bigotry and excessive violence earned the Portuguese many enemies. Other Europeans followed the Portuguese in their quest for spices, colonies, slaves and wealth. But Egypt regained its place as the prime intermediary between Europe, India and the Far East as prime supplier of spice. "By unknown means and ferried by unknown hands... spices arrived in the souks of Cairo and Alexandria and thence to the markets of Europe like so much cosmic driftwood. Arab dhows conveyed them across the Indian Ocean to the Persian Gulf or the Red Sea. At any one of a number of ancient ports-Basra, Jeddah, Muscat or Aquaba- the spices were transferred onto one of the huge caravans that fanned out across the deserts to the markets of Arabia and on to Alexandria and the Levant". ${ }^{13}$ Since

${ }^{11}$ VD Hanson, Carnage and Culture, [New York: Anchor Books, 2002] pp265269 ; Quoted from Bernard Lewis, « Some Reflections on the decline of the Ottoman Empire ", Studies Islamica, 9, 1959, p.118; AK Pasha, India and West Asia : Continuity and Change, [Delhi : Gyan Sagar, 1999] pp.7-15 ; Ibid., p.67 : See also Mawlana Syed Sulaiman Nadwi, Indo-Arab Relations: An English Rendering (Hyderabad : The Institute of Indo-Middle East Cultural Studies, 1962). ; Turner, n.3, pp.22, 42, 45-47.

${ }^{12}$ National Herald (Delhi) 28 September 1992.

${ }^{13}$ Riyaz Punjabi and A K Pasha, Ed, India and the Islamic World (New Delhi:
Napoleon's invasion of Egypt in 1798 Britain took keen interest in the West Asian region as it was then establishing its grip over India and feared a French invasion by way of Egypt. It must be pointed out here that the south Indian ruler of Mysore, Tipu Sultan looked for French help against the British during the latter part of $18^{\text {th }}$ century. After defeating Tipu in 1799 the British with the help of Indians took over much of the Arab world. In 1839 the British occupied Aden in Yemen and subsequently in 1882 they brought Egypt under their control basically to protect the communication lines between London and India. British desire to strengthen her grip over India was facilitated by her control over Egypt. ${ }^{14}$ The Suez Canal which is in Egyptian territory and opened for traffic in 1869 was an important link in the British Communication/transport lines. The Canal since then has proved to be a vital link between India and Egypt, although the British tried to reduce the relations between two ancient civilizations.

Even since Haider Ali became the de facto ruler of Mysore between 1761-1782, with control over a large chunk of South India, the British perceived him as a mortal enemy and relations had been strained. Under his son Tipu Sultan they reached a nadir primarily due to determined British efforts to isolate him and bring about his downfall. The British challenge to Haider Ali and Tipu Sultan which the former saw as a great hindrance to their interests in India and neighboring areas was one of the most formidable an Indian ruler had to face in the second half of $18^{\text {th }}$ century and in self defense both the Indian rulers had been compelled to take a series of bold measures. In the Gulf region European rivalry was common, especially British attempts to bring it under its control. It is pertinent to note that the French had already conceded defeat to the British and were confined to few pockets in insignificant areas. Having curtailed the trade and profits of the Arabs especially those belonging to the Omanis they could easily be manipulated and eventually subjugated by the British. The Ottoman Sultan due to determined attempts by the Russian Czars and mounting challenges from the Europeans had come to acknowledge British supremacy in the Gulf region in numerous ways. The Persians were busy fighting amongst themselves while it was easy for the British to foment trouble for the Afghan rulers in view of the tribal factor in Afghan politics. From all this, it is abundantly clear that the room to maneuver for Tipu Sultan internationally was extremely limited given the British naval supremacy and superior technology which enabled them to have the global reach and paramountacy. ${ }^{15}$ The British challenge to Tipu was formidable; it prompted him to respond with equally forcible, bold and prompt measures to tackle it. Most remarkable was his attempt to seek friendship with the Ottoman Sultan, Oman, France, Persia, Afghanistan and other Gulf countries, who were also, equally at the same time under intense pressure and vulnerable to British power. Despite his forced involvement in British inspired wars and the huge burden of war reparations, whenever his economic and political position improved, Tipu Sultan, sent embassies abroad as he strongly believed in close cooperation with the Ottoman Sultan,

Radiant Publishers 1998) p.97; MS Agwani, « India and the Arab World », in BR Nanda, Ed, Indian Foreign Policy: The Nehru Years (New Delhi: 1976), pp.72-3.

${ }^{14} \mathrm{~A}$ K Pasha, "Indo-Egyptian Cultural Relations: Retrospect and Prospects", in Zohurul Bari, Ed, Modern Egypt: Culture, Religion and Politics, (New Delhi: Shipra Publications, 2003) pp.199; see also Saryu Doshi, Ed; India and Egypt: Influences and Interactions (New Delhi: Garg Publications, ICCR. 1993).

${ }^{15}$ AK Pasha, "Tipu Sultan's Relations with the Ottoman Empire" Détente, [New Delhi], vol. X, nos. 4 and 5, January-April, 1992, pp.6-11; I.H. Qureshi, "The purpose of Tipu Sultan's Embassy to Constantinople", Journal of India History, Vol. 24, 1945, pp.77-85. 
Oman and other Gulf countries in order to contain the formidable threat posed by the British to his regime. Towards this end, he began to offer numerous concessions in order to induce them to support him. To the Ruler of Oman, Tipu sent a diplomatic mission headed by Mir Abdul Rahman and Mir Iyantullah. They were accompanied by Mirza Karim Beg Tabrizi the Persian envoy to Mysore. Like on previous such missions, Tipu Sultan sent valuable gifts to the Ruler of Muscat. These included jewels, elephants, khillats, sandalwood, ivory, pepper and cardamoms. It must be mentioned that Haider Ali had also maintained close ties with the Ruler of Muscat and also had an establishment at Muscat but this special arrangement lapsed as was customary with his death in 1782. Tipu's intense diplomatic activity with Oman which had essentially political, economic and military consideration only showed his desire to keep up contacts with influential and powerful rulers but also to continuously seek allies in his ceaseless quest for partners to withstand the British challenge. Thus, the guiding principles of Tipu's diplomacy were to neutralize his enemies and maintain the integrity of his Kingdom and to contain British imperialism as also their expansionism. It is significant to note, that the French also maintained close ties with the Ruler of Oman but Tipu's and the Omani ruler's relations with the French appear to have been complementary but independent. With France plunged into turmoil and instability whatever little hope Tipu Sultan had from France were dashed. This explains his decision to send a high level delegation to the Ottoman Caliph with three goals: 1] to gain recognition as an independent monarch of Mysore; 2] to seek military assistance; and 3] to explore the possibility of establishing close economic and trade relations. ${ }^{16}$

At this stage it is necessary to briefly assess the Ottoman Empire's position which was under mounting challenge from the European powers. After they took over Constantinople in 1453 the Ottoman's were undisputed naval powers in the Mediterranean. They had achieved unprecedented growth mainly due to their skill in facilitating the transport of the products from the East such as cotton, spices, silk and agricultural produce to Europe in exchange for weapons, ships and manufactured goods. The geographical discoveries by the Portuguese, Spaniards, Dutch, French, British and others and the direct sea route especially to India led to importation of gold and silver from the new colonies and takeover of orient trade adversely affecting the Ottomans. Soon the Ottomans were to suffer a terrible defeat in 1571 at the hands Italians when they were defeated in a naval battle at Lepanto. This was seen as a "watershed in the history of East-West Relations." According to one writer, "Once the Ottomans were stopped at Leponto, the continued long-term autonomy of the Western Mediterranean would never again be in doubt. Leponto ensured that the growing Atlantic trade with the Americas would continue as Europeans not only became enticed by the New World treasure but found the Ottoman Empire increasingly irrelevant to their growing commercial interests in the orient via routes around the Horn of Africa." Not only European control and hegemony over the Eastern Mediterranean was restored but the with the rise of the Europeans, the Arab-Islamic lake as the Indian Ocean was known, came to be dominated first by the Portuguese, then by the Dutch, French and soon the British became undisputed masters over the

${ }^{16}$ Quoted from Bernard "Lewis, "Some reflections on the decline of the Ottoman Empire", Studies Islamica, no. 9, 1959, p.118; see also K.N. Chandhari, Trade and Civilization in the Indian Ocean: An Economic History from the Rise of Islam to 1750 \{Cambridge: 1985); and The Trading World of Asia and the English East India Company 1600-1760 (Cambridge: 1987); Patricia Rico, Oman and Muscat: An early Modern History (London: Croom Helm, 1986). area. The secret was due the fact that the Europeans possessed large number of sophisticated ships with powerful guns than the Ottomans. This also led to the shift in focus from the Mediterranean Sea to the Indian Ocean and the Atlantic. Clearly this marked a new era in which powerful guns, cannons and ships proved to be decisive and a real strategic sense. Ottoman advantage with cavalry was not much of an asset compared to ships owned by small states like Portugal or Venice. The Ottomans saw rapid drying of capital with the highly lucrative maritime trade carried by the Europeans with India and the east in general. Bernard Lewis quotes from Umar Talib, one of the Turkish elite, who complained in 1625 that: "The Europeans have become acquainted with the whole world, sending their ships everywhere and seizing the harbors. The goods from India, Sind and China previously came to Suez and were distributed by the Muslims to the whole world. Now, however, these goods are transported by the Portuguese, the Dutch and the English to the Frankish countries, from whence they distribute them to the world. The goods that they don't need, they bring to Istanbul and the Islamic countries selling them at five times their value, thus reaping great profit. For that reason both gold and silver have become scarce in Islamic countries". ${ }^{17}$

But Tipu Sultan still perceived the Ottoman Empire as strong and hence thought of seeking assistance. As early as 1784 Tipu had sent an exploratory mission to the Sublime Porte to find out whether an Embassy there would be productive. When he told about the efficacy of having a mission at the Porte, Tipu have decided to send a large mission consisting of 900 people on November 17, 1785. The leader of the delegation was Ghulam Ali Khan and included Nurullah Khan, Lutf Ali Khan and Jaffar Khan among others. The delegation after a long and difficult sea and land journey via Muscat, Bushier, Basra, Baghdad and other places reached Constantinople on September 25, 1787. It was only on November 5, 1787 the Ottoman Sultan Salim-III received Tipu's emissaries with honor and decorated them. The Sultan accorded permission to Tipu to assume the title of an independent monarch and the right to strike coins and to have the Khutbha read in his name. The envoys were also given for Tipu friendly letters, Khillats, a sword and a shield studded with precious stones by the caliph and his Grand Wazir. With this, one of the major objectives of the mission had been accomplished. ${ }^{18}$ Tipu also sought military assistance from the Ottoman Caliph to put an end to the British menace in India. In order to impress upon the Ottoman Sultan the gravity of the situation and urgency of his demand Tipu sought to arouse the religious sentiments of the Caliph by highlighting to him the subversive and deceitful manner in which the British had become overlords of large parts of territories which actually belonged to the Mughals and other Indian rulers. More significantly in order to make sure his mission would succeed, Tipu also impressed upon the Ottoman Sultan that the British

\footnotetext{
${ }^{17}$ Virendra Verma, "Tipu Sultan's embassies to Constantinople and Kabul," Journal of Historical Research, Vol. XVI, No. 1, August 15, 1973, pp 5156; Mohibul Hassan ed, Waqai-I, Manzil-i.Rum-Tipu Sultan's Mission to Constantinople (Delhi: Aakar Books, 2005), pp.1x-xiii; pp 1-4, pp-61-63; AK Pasha, ed., Perspectives on India and the Gulf States (New Delhi: Detente Publications, 1999) pp 1-23 and pp-210-211; Azmi Ozan, Pan-Islamism: Indian Muslims, the Ottomans and Britain, 1877-1924 [Leiden: EJ Brill, 1997] pp. 11-12.

${ }^{18}$ Iqbal Hussein, "The Diplomatic Vision of Tipu Sultan: Briefs for embassies to Turkey and France, 1785-86" (Translation" in Irfan Habif, Ed; State and Diplomacy under Tipu Sultan Documents and Essays (New Delhi. Tulika Books, 2001) pp 19-65. See also Khaldoun Hasan al Naqueeb, State and society in the Gulf and Arab Peninsula: A different perspective (London: Routledge, 1990) pp 31-42.
} 
were humiliating the Muslims in India by forcibly converting them to Christianity and changing the mosques to Churches. The Ottoman Sultan found it easy to recognize as an independent King but saw his request for military assistance hard to entertain, because he himself was preoccupied with defending his possessions under challenge from the Russians, Austrians and others. He politely firmly turned down Tipu's request for a body of Turkish soldiers to be sent to Mysore to fight against the British. Actually Tipu wanted the Ottoman Sultan to send him a body of troops whose expenses would be borne by him and they would be sent back to the Porte at his expense whenever they would be required by the Caliph. In the end, the Sultan declined to provide any tangible military help to Tipu. It must be repeated that the Ottoman Sultan facing outside threats could not expect help from France due to the turmoil there leading to the revolution. In fact, Britain was busy mediating peace between Turkey and her enemiesRussia and Austria. The Ottoman Sultan therefore, was in no mood to help Tipu and lose British friendship. ${ }^{19}$ Tipu had also urged the members of the delegation to secure trade privileges with the Ottoman Empire on a reciprocal basis; he wanted facilities in Basra in exchange for Mangalore. He also wanted Turkey to help him in establishing various factories in Mysore and by sending technicians specialized in the art of making muskets, guns, glass, chinaware and other military hardware or spares and in return Tipu would send workers required by the Ottoman Sultan. The delegation carried large quantities of goods produced in Mysore with them to be sold at various ports of call so that wide publicity is given to the products and hence exports boosted. The mission costed Tipu more than 20 lakhs of rupees and out of about 900 men only a handful returned to Calicut on 29 December 1789. ${ }^{20}$ Tipu also wanted the Ottoman Caliph to mediate in settling his differences with the British. In early 1799 Caliph Salim III addressed a letter to Tipu describing the French invasion of Egypt and their plan to conquer Arabia, divide it into republics and extirpate Islam. He also wrote that the French also wanted to conquer India and deprive its people of their religion, life and property. He advised Tipu to refrain from any hostile activities against the English at French instigation and offered to adjust satisfactorily any cause of complaint that he might have against them. ${ }^{21}$ Although the British had succeeded in frustrating Tipu's attempt to get recognition from the Mughul Emperor in Delhi despite their influential presence and machinations at the Ottoman court, Tipu did succeed in gaining recognition for his independent status as a King. Even though the British were quite concerned for a variety of reasons at the recognition of Tipu, but their rapidly growing influence in India and in the vast Indian Ocean region gave them comfort and confidence about ultimately their ability to encircle and crush Tipu. It must be mentioned that the British were apprehensive of Tipu's growing contacts with the Muslim rulers both in India and abroad. His extensive links with Afghanistan, Persia, Oman, Ottoman Empire and other smaller states, his strategy aimed at intensifying political and economic cooperation particularly setting up of factories,

${ }^{19} \mathrm{AK}$ Pasha, India and West Asia: Continuity and Change, (Delhi: Gyan Sagar, 1999) pp 1-15. I. Hussein Qureshi “Tipu Sultan's Embassy to Constantinople, 1787" in Irfan Habib, ed, Resistance and Modernization under Haidar Ali and Tipu Sultan ( New Delhi Tulika, 1999) pp.69-78.

${ }^{20}$ Pasha, n.1, p.229, see also Aniruddha Roy, ed; Tipu Sultan and his Age: A Collection of Seminar Papers (Kolkata: The Asiatic Society, 2002); AK Pasha, Tipu Sultan Diplomacy in the Gulf Region, GSP, working paper No. 10, CWAAS, SIS, JNU, 1997.

${ }^{21}$ Pasha, n.2., p.9; see also K.M. Pannikar, Asia and Western Domination (London: Unwin and Allen, 1953) and Malabar and the Dutch (Bombay: 1931); M. Redha Bhacker, Trade \& Empire in Muscat and Zanzibar; Roots of British Domination (London: Routledge 1992) pp.34-5. state to state trade ignoring the Europeans, establishing military cooperation all were considered too dangerous and revolutionary ideas which if implemented could undermine their position in the area and ultimately dash their hopes of establishing an empire where the Sun would never sets. Moreover the Nizam of Hyderabad was equally disturbed at Tipu's recognition by Turkey which was a coup de grace. Since the Ottoman Sultan still enjoyed great prestige as the most dominant Muslim power relegating the Mughul Emperor to the background, the Nizam felt out maneuvered as he could no longer claim to be legally superior because "the Sultan of Mysore had a better title to his Kingdom than the Viceroy of the Deccan to his Viceroyalty" No wonder the Nizam wanted the British to wipe out Tipu for which he provided all assistance. Many of Tipu's enemies were also concerned at Tipu's not inconsiderable achievements at Constantinople and other places which brought name and fame from abroad and ended his isolation throwing his enemies in confusion. The British correctly analyzed Tipu's comfortable and secure position at home which propelled him to seek outside recognition and success; hence they did everything to pull him down from within using his enemies and their manipulative skills. ${ }^{22}$

Tipu's ambassadors on their way to Turkey stayed in Oman for about three months, from early April to late June 1786 and a journal was kept of their dealings there. The secretary credited with having written the Persian journal was Khwaja Abdul Qadir. Keeping in view the crucial role-played by the Gulf region from all dimensions, which would enable Tipu Sultan to better understand the prevailing conditions there because of its direct bearing on his Kingdom. The delegation carried large quantities of goods produced in Mysore with them to be sold at various ports of call so that wider publicity was given to the products and hence exports boosted. Tipu Sultan encouraged Omani, Arab, Persian and Armenian merchants among others to come and settle in Mysore and gave them special privileges as they were seen as successful businessmen. Even though no treaty resulted between Mysore and Oman but an extensive report on Muscati trade and opportunities was sent back to Mysore by Tipu's Ambassadors to Turkey. One of the crucial reasons why Mysore was prosperous was due to the state monopoly of trade. Tipu Sultan naturally placed severe restrictions on European trading companies especially the English. Even the French could not trade freely in Mysore. The British in order to circumvent Tipu's restrictions, used to send other merchants disguised as Muscati traders to make cheaper purchases from Mysore. Through his alert and vigilant intelligence, Tipu Sultan learnt about British cheating and he promptly instructed that only

${ }^{22}$ Sheik Ali, History of Tipu Sultan ( New Delhi: NBT, 1972) and Tipu Sultan : A Study in Diplomacy and Confrontation [Mysore: Rao \& Raghavan, 1982); see also A.K.Pasha, ed; India \& Oman: History, State, Economy and Foreign Policy (Delhi: Gyan Sagar, 1999), pp. 1-21; see also A.K. Pasha " South India and the Gulf: Trade and Diplomacy during the late 18th century", in NN Vohra, ed. History, Culture and Society in India \& West Asia (New Delhi: Shipra 2003) pp 237-249. See also Akhtarul Wasey "Turkey and Evolution of Indian Culture," Islam and Modern Age, Vol.XXXIII, no.4, November, 2002. Pp.87-94; See also R.L. Shukla, Britain, India and the Turkish Empire, 18531882. (New Delhi: People's Publishing House, 1973; B.R. Nanda, Gandhi : Pan Islamism, Imperialism and Nationalism in India (New Delhi: Oxford University Press, 2002); Najma Heptullah, Indo-West Asian Relations: The Nehru Era (New Delhi: Allied Publishers, 1991); AK Pasha "Nehru and the Crises in West Asia" Detente, vol. IX, No. 1, May-June 1990, pp 4-9; Prithvi Ram Mudiam, India and the Middle East (London: British Academic press 1994); and Saad Bin Zia, Turkish Freedom Movement and the Role of A1 Hillal of Maulana Azad (1912-14) M Phil disst (CWAAS, SIS, JNU, New Delhi 2005). 
genuine merchants who had valid passports or authorized certificates from his officials in Muscat could engage in trade at Mysore. Tipu urged foreign rulers especially the Ottoman Sultan and the Ruler of Oman, to send him skilled people and technicians who would assist his government in the setting up of modern industries. This was possible due to his wide knowledge of the advanced countries in the West, extensive foreign trading contacts and familiarity with foreign goods apart from foreign languages. Thousands of foreign skilled workers were brought in and among them Turks, Arabs, (especially Omani) Persians, Afghans were also present. They not only brought their technical skills but by their interaction with locals a new vision of modern world was projected. According to one writer, "No other sovereign in Indian history had given such an impetus to industrial production with foreign collaboration". ${ }^{23}$ Thus, he undertook the role of an international trader, manufacturer, banker and moneychanger. In most of these areas, Tipu was close to Mohammed Ali, the founder of modern Egypt. Tipu's tremendous interest in international trade and other foreign economic matters in the midst of battles, challenges from the British and other threats, reveals his far sightedness and realization that promotion of commerce and industry was the true strength of his Kingdom. According to one writer, "If Tipu Sultan had been allowed to rule Mysore peacefully for a few more decades, there is little doubt that he would have brought about an economic revolution of the first magnitude. The seeds which he sowed did however bear fruit after his death and the state of Mysore, long before

${ }^{23}$ see also Aniruddha Roy, ed; Tipu Sultan and his Age: A Collection of Seminar Papers (Kolkata: The Asiatic Society, 2002); AK Pasha, "Tipu Sultan Diplomacy in the Gulf Region", Gulf Studies Programme, Working Paper No. 10, CWAAS, SIS, JNU, New Delhi, February 1997; “Tipu Sultan's Relations with the Ottoman Empire", Detente, vol., no.4 and 5, January-April 1992, pp.6-11; see also Wrike Freitag and William G. Clarence Smith Ed; Hadhrami Traders, Scholars and Statesmen in the Indian Ocean, 1750's-1960's (Leiden EJ Brill, 1997); VD Hanson, Carnage and Culture, [New York: Anchor Books, 2002] pp. 265-269 ; Richard Hall, Empires of the Monsoon: A History of the Indian Ocean and its Invaders. [London: Harper Collins, 1998] pp.195-224; B.R. Nanda, Gandhi : Pan Islamism, Imperialism and Nationalism in India (New Delhi: Oxford University Press, 2002); VD Hanson, Carnage and Culture [New York: Anchor Books, 2002] pp.267-269; Richard Hall, Empires of the Monsoons: A History of the Indian Ocean and its Invaders [London: Harper Collins, 1998]; Allen Calvin, Sayyids, Shets and Sultans: Politics and Trade in Masqat under the Al Abu Said 1785-1914, Ph.D. Thesis University of Washington, (Seattle), 1978; and Pamela Nightingale, Trade and Empire in Western India 1784-1806 (Cambridge: CUP, 1970); Denys Lombard, Jean Aubin, eds., Asian Merchants and Businessmen in the Indian Ocean and the China Sea, [New Delhi: OUP, 2000]; John Jeay, The Spice Route: A History, [London: John Murray, 2005] ; Martin, Dispatches, Minutes Correspondence of Wellesley, vol.1, pp.307-8, cited in Ibid, p.55; Forrest, no.7, p.244; Sultan, Muhammad Al Qasimi, The Myth of Arab Piracy in the Gulf (London: 1988), pp.22-28; AK Pasha, "Tipu Sultan and Saddam Hussein: Regime Change-History Repeats Itself”, paper presented in a National Seminar on Contemporary Oman and Emerging Indo-Omani Relations, 25-26 October 2005, organized by Gulf Studies Programme, Centre for West Asia and African Studies, School of International Studies, Jawaharlal Nehru University, New Delhi; See the text of Treaty of Friendship and Culture Agreement in AK Pasha, India and Turkey: Past and Emerging Relations [Delhi: Academic Excellence, 2006] pp.159-161; see also Mushirul Hasan and Margaret Pearson, ed, Regionalizing Pan Islamism; Documents on the Khilafat Movement (New Delhi, Manohar, 2005); Sanjay Sanjay Subrahmanyam, Explorations in Connected History: Mughals and Franks, [New Delhi: Oxford University Press, 2005]; AK Pasha, "India and West Asia: Continuity and Changes" in Nalini Kant Jha, Ed, Indian Foreign Policy in a Changing World (New Delhi: South Asian Publishers, 2000) pp.240-269; AK Pasha, "India's Cultural Diplomacy in West Asia", in AK Sinha and AK Singh eds., Udayana: New Horizons in History, Classics and Inter-Cultural Studies, [Delhi: Amanika Publications, 2007] pp.295-310. the era of planning, was in the vanguard of industrial progress and public welfare in India." It was due to Tipu's efforts that Mysore which is now called Karnataka has become India's leading silk producing state. Silk industry was developed in Mysore by obtaining silk worms from Muscat and by encouraging the plantation of mulberry trees. It was also due to Tipu's efforts that a huge quantity of sandalwood was sold in the Omani markets. Tipu Sultan gave all the incentives to grow sandalwood and saw to it that the wood and oil were exported to foreign countries especially to Oman where there was large demand. Mysore owes an immense debt of gratitude to Tipu Sultan to this day, sandal wood and oil is exported to Oman and other parts of the Gulf region. Tipu's foreign economic diplomacy, which primarily aimed at increasing My sore's exports through state trading even though fell short of his hopes, but was largely successful in trade with Muscat due to his pragmatic plans. This has to be considered Tipu Sultan's most significant commercial success. The British viewed Tipu Sultan as a dangerous competitor and their goal was to put an end to all his trading activities and imaginative enterprises. Tipu's factories and Agency at Muscat that was intended to improve trade between the two states was closed down after his death in May 1799.24 The ruler of Muscat did not endear himself to the English by his friendly dealings with Tipu Sultan. After Tipu's defeat, the British ordered the Imam of Oman to stop the French and Dutch ships from trading to and from Muscat, as this was not only a threat to their own trade but in fact they were actually at war with the British during this entire period. Tipu Sultan's relations with Oman charted new and unprecedented course except for Haider Ali's limited initiative in this field. His embassies/missions to Oman and other Gulf countries not only gave him legitimacy to his rule (which was denied by his neighboring Indian rulers and the British, but with other countries even though he could not get the help he anticipated) but had flourishing trade with them like Muscat, Aden, Persia, Afghanistan. These were undoubtedly bold and courageous initiatives, basically a response to the massive challenge from the British, taken by a shrewd and ambitious ruler who had a clear global vision. Undoubtedly, Tipu's shrewd diplomatic initiatives in the Gulf region especially his ties with Oman were bold, imaginative

${ }^{24}$ See also Mawlana Syed Suleiman Nadwi, Indo-Arab Relations: English rendering (Hyderabad: The Institute of Indo-Middle East Cultural Studies, 1962); For details see R C Majumdar et al. An Advanced History of India (Delhi: Macmillan, 1978), p. 346. See also MN Pearson, Merchants and Rulers in Gujarat: The Response to the Portuguese in the 16th Century, [New Delhi: Munshiram Manoharlal Publisher, 1976] pp.67-85; see also Saryu Doshi, Ed; India and Egypt: Influences and Interactions (New Delhi: Garg Publications, ICCR. 1993); Rennell J., Memoirs: Marches of the British Armies in India during the Campaign of 1790 and 1791 (London: 1972); P.C XXXIX cited in Mohibbul Hassan, History of Tipu Sultan (Calcutta: 1971) p.392-3; B.S. Gidwani., The Sword of Tipu Sultan (New Delhi: 1989), p.239-40; Roger M. Savory, "The History of the Persian Gulf 600-1800", in Alvin Cottrell, ed., The Persian Gulf States -A General Survey (Baltimore, MD: 1980), pp.38-39; Vikram Sampath, Splendours of Royal Mysore: The Untold Story of the Wodeyars [New Delhi: Rupa and Co, 2008] ; Sultan Muhammad al Qasimi, The Myth of Arab Piracy in the Gulf (London: 1988) pp. 26-28; Praxy Fernandez, Storm over Seringapatam: The In crucible Story of Hayder Ali and Tipu Sultan (Bombay: 1969) p.163 and 211; A.D. Gupta, Malabar in Asian Trade 1740-1800 (Cambridge: 1967); A-Leevis "Maritime Skills in the Indian Ocean, 1500-1968", Journal of the Economic and Social History of the Orient, vol. 6, 1973; see also B.J Hamilton, "The Role of Monopoly in the Overseas Expansion and Colonial Trade of Europe before 1800", American Economic Review, Vol. 38, 1948; and A. Das Gupta, India Merchants and the Decline of Surat (Wiesbaden: 1979); and A.H. Abu Hakima, History of Eastern Arabia, 1750-1800 (Beirut: 1965); Edward Simpson and Kai Kresse, eds., Struggling with History: Islam and Cosmopolitanism in the Western Indian Ocean, [New Delhi: Hurst and Co, Foundation Books, 2007] ; 
and he was largely successful. Unfortunately, his skillful diplomacy pushed the British to redouble their efforts to neutralize Tipu's diplomatic initiatives, friendships and achievements. The British due to their worldwide contacts and modern means of transport and communication net works were able to reach out to places where Tipu Sultan intended to send his envoys, much faster and take effective and tangible steps to neutralize in advance his initiatives. Since the other Europeans including the French, had already been elbowed out by the English effectively from the Gulf region, it was far easier for them to frustrate Tipu's energetic diplomatic moves. The room to maneuver for Tipu Sultan was extremely limited as the British concentrated all their power, skills and resources to bring about his downfall. It must be mentioned that Tipu Sultan was ready for a conditional compromise or reconciliation with the British which would allow him to rule as an independent ruler and not as a subordinate ruler while other Indian rulers had submitted meekly to the British; but all his [Tipu's] overtures were spurned by the British and he was repeatedly rebuffed because they considered him an adversary and his ideas too dangerous and hence they decided to eliminate him. It must be recalled that since Napoleon's invasion of Egypt in 1798 Britain took keen interest in the entire West Asian region as it was then establishing its grip over India and feared a French invasion by way of Egypt. After defeating Tipu, the British with the help of Indians soldiers and resources took over much of the Arab world. In 1839 the British occupied Aden in Yemen and subsequently in 1882 they brought Egypt [little earlier Sudan] under their control basically to protect the communication lines between London and India. British desire to strengthen her grip over India was facilitated by her control over Egypt. The Suez Canal which is in Egyptian territory and opened for traffic in 1869 was an important link in the British Communication/transport lines. The Canal since then has proved to be a vital link between India and Egypt, although the British tried to reduce the relations between the two ancient civilizations. ${ }^{25}$

${ }^{25}$ see also Denys Forrest, Tiger of Mysore :The Life and Death of Tipu Sultan (New Delhi : 1970) p. 117; Sanjay Sanjay Subrahmanyam, Explorations in Connected History: From the Tagus to the Ganges, [New Delhi: Oxford University Press, 2005] ; Muzaffar Alam and Sanjay Subrahmanyam, eds, Indo-Persian Travels in the Age of Discoveries, 1400-1800, [New Delhi CUP, 2007]; see also K.M. Pannikar, Asia and Western Domination (London: Unwin and Allen, 1953); ----- and Malabar and the Dutch (Bombay: 1931); M. Redha Bhacker, Trade and Empire in Muscat and Zanzibar: Roots of British Domination (London: Routledge 1992) pp.34-5; Marie Francoise Boussac, Jean-Francois Salles, A Gate Way from the Eastern Mediterranean to India: The Red Sea in Antiquity [New Delhi: Manohar, 2005] ; ------------, Athens, Aden, Arikamedu: Essays on the interrelations between India, Arabia and the Eastern Mediterranean, [New Delhi: Manohar, 2005] ; Himanshu Prabha Ray, Archaeology of Sea Faring: The Indian Ocean in the Ancient Period [New Delhi: ICHR, 1999]; B. Sheik Ali, History of Tipu Sultan ( New Delhi: NBT, 1972) and Tipu Sultan : A Study in Diplomacy and Confrontation [Mysore: Rao and Raghavan, 1982); see also A.K.Pasha, ed; India and Oman: History, State, Economy and Foreign Policy (Delhi: Gyan Sagar, 1999), pp. 1-21; see also A.K. Pasha "South India and the Gulf: Trade and Diplomacy during the late 18th century", in NN Vohra, ed. History, Culture and Society in India and West Asia (New Delhi: Shipra 2003) pp 237-249. See also Akhtarul Wasey "Turkey and Evolution of Indian Culture," Islam and Modern Age, Vol XXXIII, no.4, November, 2002. Pp.87-94; See also R.L. Shukla, Britain, India and the Turkish Empire, 1853-1882. (New Delhi: People's Publishing House, 1973

\section{Conclusion}

To sum up, in the final analysis Tipu Sultan should be seen as India's first serious freedom fighter who clearly saw British evil intentions of subjugating India. It's unfortunate that other Indian rulers instead of supporting his efforts opposed him and became collaborators with the British. It must also be mentioned that Tipu's historical stature is guaranteed by two great qualities that he showed through his state craft: his ability to take innumerable diplomatic initiatives that transcend the force of circumstance and his ability/willingness to take enormous risk even in the face of setbacks and formidable forces. In the ultimate analysis, all of Tipu Sultan's intricate, complex international maneuvering, risks, initiatives, friendships and negotiations were primarily aimed at upliftment, prosperity, providing security and improving the life of the people and making Mysore a truly developed state like Britain or France were at that time.

\section{Acknowledgements}

None.

\section{Conflict of interest}

Author declares that there is no conflict of interest.

\section{References}

1. Childe. The Most Ancient East. In: Sudhansu KR, editor. Prehistoric India and Ancient Egypt. NewDelhi: Cambridge Book and Stationary Store; 1956. p. 39,208 .

2. Shereen R. Encounters: The Westerly Trade of the Harappan Civilization. London: OUP, 1980

3. Jack T. The History of a Temptation. New York: Vintage Books; 2005. $204 \mathrm{p}$.

4. Murray A. The Splendour that was Egypt. New Delhi: Cambridge Book and Stationary Store; 1956. p. 21.

5. Maqbul A. Indo-Arab Relations: An Account of India's Relations with the Arab World from Ancient upto Modern Times. New Delhi: ICCR, Turner; 1969. p. 238-9.

6. Shereen R. Understanding Harappa Civilization in the Greater Indus Valley. New Delhi: Tulika; 2001

7. Mohammed HZ. India and Egypt: Modern Relations between two Ancient Nations. NewDelhi: ICCR, Turner; 1984. p.12,147.

8. Abdullah M. Arabian Gulf during the British Era: The Impact of India. In: NN Vohra, editor. History, Culture and Society in India and West Asia. New Delhi: Shipra, IIC; 2003. 109 p.

9. Saryu D. Influences and Interactions. India and Egypt: Influences and Interactions. New Delhi: Marg Publications, ICCR; 1993. 13 p.

10. Mansouri SM. Art and Culture of India and Egypt. Calcutta: KL Mukhopadhyay; 1959. 46 p.

11. Chaudhuri KN. Trade and Civilization in the Indian Ocean: An Economic History from the Rise of Islam to 1750. New Delhi: Munshiram Manoharlal Publishers; $1985.59 \mathrm{p}$.

12. Andre W. Al Hind: The Making of the Indo-Islamic World vol I. New Delhi: OUP; 1999. 